\title{
Institutional Economics, Risk Management, and Breakdown of Corporate Social Responsibility: Towards a New Architecture of Financial Markets
}

\author{
Hans-Georg Petersen, Alexander Martin Wiegelmann \\ Faculty of Economics and Social Science, University of Potsdam, Potsdam, Germany; Tax and Transfer Research Group, Berlin, \\ Germany. \\ Email: hg@profpetersen.de
}

Received 2013

\begin{abstract}
The breakdown of the financial markets in fall 2007 and the following debt crisis in the EU have produced an enormous mistrust in financial products and the monetary system. The paper describes the background of the crisis induced by functional failures in risk management and the multifold principal agent problems existing in the financial market structures. The innovated nontransparent financial products especially by the so-called shadow banks have mixed up differential risk weights and puzzled or even fooled formerly loyal customers. Contemporaneously abundant liquidity on the international financial market accompanied by easy money policies of the Fed in the US and the ECB in the euro zone have depressed the real interest rate to zero or even negative values. Desperate investors are seeking for safe-assets but their demand remains unsatisfied. Low real interest rates and the consequently lacking compound interest effect in the same time jeopardize private as well as public insurance schemes being dependent on capital funding: the demographic crisis becomes gloomy. Therefore, the managers of the financial markets have to reestablish CSR and to separate the markets into safe-asset areas for the usual clients and "casino" areas for those who like to play with high risks. Only with transparency and risk adequate financial products the lost commitment can be regained.
\end{abstract}

Keywords: Capital Funding; Corporate Social Responsibility; Financial Markets; Principal Agent Problems; Risk Management

\section{Introduction}

In complex, democratically steered market societies beside the citizen, who are the principals in the political as well as economic spheres, the corporate and the government sectors have to serve the individual interests of the citizen. The managers in the private corporations as well as banks and the public institutions are the agents, being controlled via competition on more or less efficient markets or the voting mechanisms in the political setting. From both sectors the principals need the best information to evaluate the quality of the agent's performance and to control their actions. Principal-agent-problems (PAP) arise, which jeopardize the welfare development in the whole society if information is asymmetric in favor of the agents and the control intensity of the principals is not sufficient. Agents start to hide risk and misinform the principals, decision making regarding investment of equity capital and involvement in public affairs becomes highly difficult [1]. Hence, institutional arrangements (regulations) to assure transparency on the economic and political markets are of utmost relevance to prevent the agents from exploitation strategies, which are played against the principals.

Without doubt the monetary sector plays an important role for the growth processes in emerging as well as highly developed countries. In real life always the risk is involved that the power of one sector might become dominating and even endanger the future development of a well-balanced societal system. The modern monetary system is a fundamental invention of mankind. The welfare of a society is created in the productive sectors, e.g. the primary (agricultural) and the secondary (industrial) sector. With increasing labor division and specialization the complexity of a society is strongly increasing so that a highly developed monetary sector (as important part of the tertiary sector) is a basic prerequisite to improve the growth potential of a society. The implementation of a monetary system dramatically reduces the transaction costs of a barter economy and works almost as a "lubricant" for the further development process. There is no doubt about: the financial sector has contributed substan- 
tially to the welfare gains in highly developed societies. It serves as intermediary in between the lenders (savers) and borrowers (investors) and has to manage the credit risks at maximum risk transparency for all market participants and the public.

But as usual - there is a reverse side of the coin: A monetary system has to play a supportive role for the economic process because the welfare is predominantly created by the primary and secondary sectors. While in the primary and secondary sector equity capital of the business owner (sole trader or shareholder) is dominating, the financial sector is much more dependent on deposits and borrowed funds: the Basel II Accord demands an equity capital (minimum capital requirement) to secure a banks solvency, which has to be in between 1.6 and 12.5 $\%$ depending on the individual risks structure. Furthermore bank capital is difficult to define and highly volatile. Since banks are predominantly working with borrowed capital, issues are involved, which have been described by modern institutional economics: the principal-agentproblem and moral hazard. Hence, state (and international) regulations for the financial sector (banking and insurance system) are necessary to protect the investors and capital owners (principals) against exploitation by the managers of the financial sector (agents), which in reality often show moral hazard behavior in taking too much risks for the borrowed capital. If efficient regulations are badly missing, fraud and corruption destroy fairness and justice leading to mistrust in governance in the private and public sector, respectively.

\section{Financial Architecture in Transition}

The political changes in Europe in the late 80ties of the last century have led to a process of liberalization and globalization of the financial markets without sufficient adaptations regarding the traditional macro-steering of the monetary policy as well as the regulations for the banking and insurance markets. Therefore, beside the conventional banks (like commercial banks in the European tradition) a so-called shadow banking sector emerged, which at least temporarily has dominated the private sector lending. Even in emerging markets like in China, in which the strongly regulated and restricted banking system bears a resemblance to the currency theory, ${ }^{1}$ where central bank money is allowed as only legal payment instrument, a considerable shadow financial sector arose. This growth took place in the "shadow of the traditional state regulations" and even in the Basel Accords many shortcomings were involved, so that all

$\overline{{ }^{1} \text { For details see [2]. Most modern banking systems are following the }}$ banking theory [3]. ingredients were mixed up for a super crash on the liberalized international financial markets.

\subsection{Traditional Banking and Insurance System}

The European style of the monetary system is a system in which in accordance with the banking theory the commercial banks are allowed to create credits on the basis of the central bank deposits. Traditional monetary policy instruments (like the minimum reserve policy) determine the so-called credit creation multiplier; central bank money (M0), bank money and other near money assets (money at call, time deposits etc.) are forming the money supply in an economy (M1, M2, M3). The returns on credits have to cover the bank costs and potentially generate profits while at the same time safeguarding the bank depositors via accumulating sufficient equity capital as risk buffer for unexpected liability cases (connected with consumers protection). Beside the central bank based credit creation commercial banks could also take credits from private clients, capital markets or other banks (interbank transactions), which also has to be fractionally assured by underlying equity capital, so that in addition to the credit creation multiplier an additional leverage effect has been implemented. The commercial banks have to safeguard that the maturity and/or liquidity patterns of the lent and borrowed money coincide, not to get illiquid and to run into insolvency. As important as the matching of these patterns is the correct evaluation of the credit risk. ${ }^{2}$ If credit defaults occur, at first the equity capital of the bank is liable so that the capital base of the bank is weakened, being another reason for possible bank insolvency.

The credit risks are directly checked by the credit creating banks themselves (house bank system, which is nontransparent for outsiders) or more recently more often indirectly by CRA, where the rating results are public but the evaluation methods only known by the respective rating agency and consequently also nontransparent for outsiders. Limited or even false information creates asymmetries in favor of the agents (bank managers, asset managers, CEOs of the rating agencies etc.) regarding credit risks, which might be exploited by higher remuneration and bonuses.

\footnotetext{
${ }^{2}$ Until the implementation of the international accounting standards (IAS, IFRS etc.) the traditional German setting in accounting and balancing adhered the lowest value principle to protect the depositors and consumers. In banking this principle very strictly limited the credit creation possibilities so that it was substituted by the Anglo-Saxon true (or fair) value concept. The true value is a value deemed accurate and reasonable by the person who prepared a statement. Compared to the lowest value, usually the fair value is considerably higher and consequently bears a much higher risk of error. Therefore, fair value evaluation is a more subjective value and part of risk management, which has to be controlled by external agents (like banking supervision or CRA).
} 
The insurance system is closely linked to the banking system because of a partly similar role in the economy. Insurances are also managing risks (biometric and real asset risks), which necessitates the protection of the clients premiums (deposits) via capital funding. The investment of the capital funds has been usually organized with assistance of the commercial banks, temporarily following the one-stop finance concept. ${ }^{3}$ Hence, the insurances are the most important institutional investors and the largest lenders in the credit transformation processes. Because of the interlinking with the banking system, insurances are usually more or less directly infected by problems generated in the banking system. Additionally insurances are influenced by monetary policies, which have direct impacts on the real interest rate of their assets. Especially the performance of life insurances is heavily dependent on the long-termed compound interest effect, which might mitigate the consequences of demographic change in the highly developed countries. In case of low or even negative real interest rates, low returns on equity of even losses would reduce the important compound interest effect, impair the insurability of biometric risks and capital funding as alternative to the today's dominating pay-as-you-go systems and make the future perspectives even more gloomy [5].

The problems of the traditional banking and insurance schemes are to be seen in several reasons; the first important one was overemphasizing the deposit protection ("investment grade obsession") in the interests of the bank clients (consumer's protection) in the last decades of the last century. The second important problem was created by over-stressing public interventions to assure price- and systems-stability, likewise to guarantee the security of the whole money supply system. Thirdly, the credit creation took place only on the basis of specific collaterals being predominantly real assets (like mortgages and pawns, the so-called asset-based-lending where the credits remained in the credit creating bank and were not traded). ${ }^{4}$ Only in exceptional cases nonmaterial values (goodwill of a company, individual credit-worthiness, socalled relationship or projected-cash-flow-lending) have been taken as bank securities, being much higher risky as real assets, which in case of misevaluation occasionally led to bankruptcy of single banks (the typical house banks). Last but not least public guaranteed bank deposits and public debt titles have been generally presumed as trustee stocks (dominating as assets in the insurance schemes) and as a perfect substitute for central bank

\footnotetext{
${ }^{3}$ Presently the involvement of insurances in the banking based credit transformation has been reduced because insurances are more engaged in the market based credit transformation [4].

${ }^{4}$ These first problems might be also true for China, because here credit ratios and capital controls are implemented.
}

money. ${ }^{5}$

However, the credit creation potential of such a traditional banking and insurance system turned out to be too restrictive for creating a sufficient credit supply for the borrowers and a fair return on investment for the lender. The credit crunch in some decades of the last century has obstructed growth and development - the keywords were capital shortage for risk capital and under-financing of small and medium enterprises (SME). The limited ability of the traditional system to create necessary credit volumes was accompanied by an excess supply of liquidity on the international financial markets, originating from the dramatically increasing rate of return on raw materials (especially energy products) as consequence of the 1990 change and the increased central bank money supply in the US owing to overcome the crisis of the dot. com-bubble in 2000 and 9/11 in 2001.

\subsection{Evolution of the Market Based Credit Transformation}

Financial innovations at the end of the last century have been the most important prerequisite to overcome credit crunch and growth retardation. The invention of new financial institutions and products has been the outcome of the process of liberalization and globalization in the following two decades. Already in the Thatcher era in the United Kingdom and the Clinton administration in the United States it has become obvious that public debt titles were losing in relevance and new financial market segments had to be developed to meet the increasing demands for attractive financial products. The branch of the investment banks was strongly growing, in the first phase dealing predominantly with securitizing receivables of larger enterprises thereby inventing collateralized debt obligations (CDO). Parallel to that process the investment banks introduced the securitization of mortgages creating the collateralized mortgage obligations (CMO), which in the further course of the development have paved the way for the subprime mortgage crash (see below).

In the following periods a highly complex system of new institutions and financial products has been invented. Conventional or commercial banking was supplemented by a "shadow banking system" (non-deposit banks like hedge funds, structured investment vehicles, investment banks, private equity funds, money market funds, insurers etc.). These "shadow banks" do not have a banking license and the allowance to create banking money by the

\footnotetext{
${ }^{5}$ In the Basel Accords the minimum capital requirement for public debt securities from OECD countries has been zero independently from the factual risk situation of the borrowing country.
} 
credit creation multiplier. They only are based on the equity capital of their owners, which is borrowed to external clients. But via the debt service returns and the possibility to securitize their credit titles (substitution of bank credits by tradable securities, e.g., ABS), the credit leverage of that banks has been extended and an additional leverage effect was invented, which has also multiplied the possible credit volumes. ${ }^{6}$ This vehicle is also used by commercial banks. Beyond that leverage effect the invention of bad debt insurances has created another leverage impact: For higher risky collateral the risk component of such an asset is separated from the stock and transferred via credit default swaps (CDS) to debt insurances, which relief regulated banks from risk buffer constraints also increasing the credit volume. As long as the risk evaluation is done by reliable risk managers and controlled by efficient and independent CRA, such a high leverage system might function. If the agents (risk and asset managers) are behaving in the sense of PAP and moral hazard, ${ }^{7}$ such a system degenerates to a pure Ponzi game. ${ }^{8}$ Then the limits from adequate risk management to fraud and criminal actions are clearly surpassed.

No wonder that the credit volume of the shadow banking system was permanently increasing and outpacing the credit volume of the commercial banks ( Figure 1). If then the commercial banks are trying to catch up in buying such contaminated assets (“junk bonds”) or even starting similar credit procedures, the commercial banking system and the insurance system itself become infected, too.

The real shortcoming and threat for the existence of a sound financial system was the fact that the shadow banking system was not sufficiently under control and supervision. Regulatory and supervisory measures of respective jurisdictions did not sufficiently account for all these changes; neither did supranational rules such as the Basel Accords (Basel I and II). The financial innovations as well as the new financial institutions were permanently becoming more and more complex so that the information on the real risk structures of the different investment products became increasingly opaque. This was especially true for the multiple securitization struc-

\footnotetext{
${ }^{6}$ Because of the strongly increasing credit volumes the US Fed in 2006 stopped to report the further development of M3 just in a period where a substantial increase of M3 was observed. In macro-prudential view a traditional measure of monetary expansion was badly missing, which had impaired the critical analysis of the systems impacts of credit transfer instruments in the US [4].

${ }^{7}$ That does mean that both groups of persons involved in that process are maximizing their personal incomes in the shortest possible time, thus possibly causing a crash of the whole financial system.

${ }^{8}$ The most prominent example is the subprime debt market, where refinancing occurred through increasingly opaque financial structures until the realization of value depreciations caused the entire system to collapse.
}

tures, where even experts were not able to evaluate the product quality.

This innovation process was accompanied by a growing relevance of the CRA, which became the external evaluators for the credit creation processes in the commercial as well as shadow banking area. At the beginning the ratings have been limited to CDO's of large corporations but step by step the CRA have won influence even in evaluating public debt titles. ${ }^{9}$ The fact that CRA have been paid by the own clients (corporations and jurisdictions being rated themselves) and have been personally closely linked by staff exchanges with the banks supplying the credit titles under consideration have impaired the objective evaluation processes so that serious evaluation failures or even corruption and fraud might have been involved in many cases. This has been demonstrated by the false evaluation of the rating agencies (Standard \& Poors's, Moody's, Fitch Rating), interestingly being all US private companies. Obviously there has been no product liability for financial products - neither on the national and nor on the international level - while the product liability for industrial products is highly stringent even on an international basis.

Consequently a flood of new financial products was invented to attract the excess supply of capital: asset backed securities (ABS), the already mentioned CDO and $\mathrm{CMO}$, collateralized loan obligations (CLO), collateralized bond obligations (CBO), collateralized insurance obligations (CIO), credit linked notes (CLN), credit default swaps (CDS), other types of true-sale and synthetic securitizations of different forms of debt, derivatives and future markets, secondary markets for re- or multiple securitizations).

Experienced bankers and even highly professional asset managers were sometimes overburdened in correctly assessing the new products especially regarding the complex risk structures.

Without doubt the evolution of the so-called marked based credit transformation has substantially increased the credit volumes in the national economies and solved the problem of the credit crunch of the last decades before the process of liberalization and globalization. But as typical in economics everything is connected with opportunity costs, which in this case have especially been complexity and risk non-transparency. As already mentioned before national and supra-national (Basel Accords) regulations continued for the traditional commercial banks and insurances; principally necessary adaptations for the emerging shadow banking system remained undone, the marked based credit transformation was left to one's own devices. As consequence of the lacking regu-

\footnotetext{
${ }^{9}$ For details on the problems with CRA see [6].
} 
lations the financial intermediaries (provider of financial products) and CRA were exclusively following their own interests (profit and remuneration maximization), the financial sector gained dominance over the real economic sector.

The involved bankers and asset managers obviously were not following the often propagated guidelines of corporate social responsibility (CSR) [7]; they have not acted as decent tradesmen ("ehrbare Kaufleute"), which in the German literature is the basis for the concept of CSR [8]. Dubious financial products flooded the market based credit transformation (Figure 1) and overdrew the credit volume in maximizing the leverage effect and minimizing the equity capital reserves. Investors and consumer's as well as depositor's protection beside the public deposit guarantees were almost totally neglected. All problems discussed in the theory of new institutional economics emerged, just to mention PAPs, moral hazard and the collapse of all ethical guidelines - in view of the public the "honest banker" mutated into the "bangster", which is the combination of banker and gangster.

Especially in the USA a shadow banking system emerged, which tremendously gained in relevance and even started to dominate the classical banking structures (Figure 1). ${ }^{10}$ In such an environment "subprime mortgages" (in reality an irresponsible Ponzi game) could be "invented", which have almost destroyed the monetary system in the 2008 crisis. The exaggerated risk behavior of the US shadow banks, which in the first in- stance have created high profits, has also infected the behavior of the European banks (especially of the Deutsche Bank, which US establishments played a very questionable and devastating role ${ }^{11}$ ).

In a short term perspective even very dubious profits made by debt financing and extreme risk taking increase the rate of return, which induces rising market capitalizetion at the stock markets. If conventional banks are not following, they are losing in market capitalization and are endangered by an unfriendly takeover. Therefore, more and more banks had to take increasing risks positions for the survival in a strongly increasing footrace for a better competitive position - finally leading into the almost collapse of the financial system.

The widening of the financial markets has increased the pressures on the commercial banks and insurances to move into business segments, which formerly were in the hands of specialized financial institutions (like investment banks, private equity funds, hedge funds, etc.). Even German banks with high reputation temporarily have lost

\footnotetext{
$\overline{{ }^{10} \text { In chart } 1 \text { ABS means asset backed securities and CDO collateralized }}$ debt obligations.

${ }^{11}$ See the unmasking article in Der Spiegel, No. 5, 30.01.2012: "Die Zocker AG - Die dubiosen Geschäfte der Deutschen Bank”.
}

the interest in their smaller private client segment and concentrated on big firms and investment banking. The short-termed windfall gains induced a process of mergers, which has substantially increased the concentration being a threat for future competition. Similar processes have taken place all over the world so that only few and big banks remained, which are called "systemic" banks, being too big to fail, because their bankruptcy would now endanger the existence of the national or supranational financial system, or to connected to fail, because their bankruptcy would endanger the all the other institutions in the ABS production chain. All this has been accompanied by more or less inefficient CRA being private firms, which are not at all adequately regulated - by neither the national states nor international organizations. This has led to the outcome that an increasing number of experts and citizen has lost confidence in financial institutions despite of the fact that financial products are predominantly "credence goods".

\section{Empirical Pictures of the Crisis}

The international financial markets have been characterized by a high and increasing liquidity in last decades, especially after the liberalization as consequence of the fall of the iron curtain. Additionally the periods of consolidation in the budgets of the US and the UK mentioned above have induced innovations in the financial markets, which have strengthened the leverage effects and enlarged the credit potentials. Increasingly risky financial products accompanied by the introduction of the new currency in Europe (euro) have led into the financial crisis, in which the exploding public debt in the euro zone has contributed additional risks for a gloomy perspective.

\subsection{Financial Innovations and High Yielding Bonds in the US}

As mentioned before especially the increasing resource rents in the primary materials producing countries have flooded the international financial markets since the beginning of the 1990ties, which had just been almost totally liberated after the 1990 change. Additionally a long period of strong economic growth was observed in the emerging BRICS (Brazil, Russia, India, China, and South Africa) nations. The raw material producing and emerging countries were not able to absorb all the export surpluses in their own countries so that especially their governments and/or banks were looking for profitable investments especially in the high developed industrial nations. The alternative investment in the really needy developing countries (often being "fragile states" [9]) did not take place because of the supposedly lacking "in- 
vestment security" so that their growth remained comparatively moderate. The excess of saving over desired investment in the past two decades has been absorbed in the highly developed countries - the US and the member states of the European Union. Here the investment took place predominantly in the new financial products and government bonds. The excess liquidity and the policy of cheap money in the US and Europe has set the questionable incentive to reduce savings in the high developed countries and to increase their foreign debt [10].

The empirical development in the USA, which has generated the financial crisis of 2007/08, is shown in the following Figures 1 and 2. Figure 1 demonstrates that since 1985 the relevance of the shadow banking system (supplying the "financial innovations") was permanently increasing. The growth of the market based credit transformation by the largely unregulated ABS issuers outpaced the growth of regulated conventional bank products; in 2008 the volume of the shadow banking sector reached its peak with about USD 20 billion compared to the conventional banking sector with about USD 11 billion.

The so-called true-sale securitizations are divided into the conventional ABS and collateralized debt obligations (CDO). Conventional ABSs consist of broadly diversified and homogenous receivables; its credit worthiness can usually be estimated by actuarial mathematics. However, CDO is an umbrella term for structured debt, collateralized by much more heterogeneous assets like credits of private companies partly traded on the stock exchange, illiquid property, real estate credits (CMO), payment requests for automobile loans, credit cards loans, student loans, consumer credits, public debt titles etc. Additionally CDOs themselves have been securitized again (re- or even multiple-securitization) so that for the customers the risk structures usually were totally hidden.

Figure 2 represents the breakdown of true-value securetizations in the US and its development since 1985. The figure illustrates that the subprime mortgages have permanently won in relevance and the same is true for the CDOs. However, especially highly complex and risky products have dominated the markets for true-sale-securitizations.

Hence, an efficient individual risk management was not any longer possible. At least the higher yield for some of the products was a rough hint that the involved risks were steadily increasing. And all that has happened without any information and warnings for the involved customers. Liability and responsibility considerations have obviously not taken place on side of the product innovators and any product recall - as it is usual for defective products in the industrial and consumption goods sectors - has never happened.

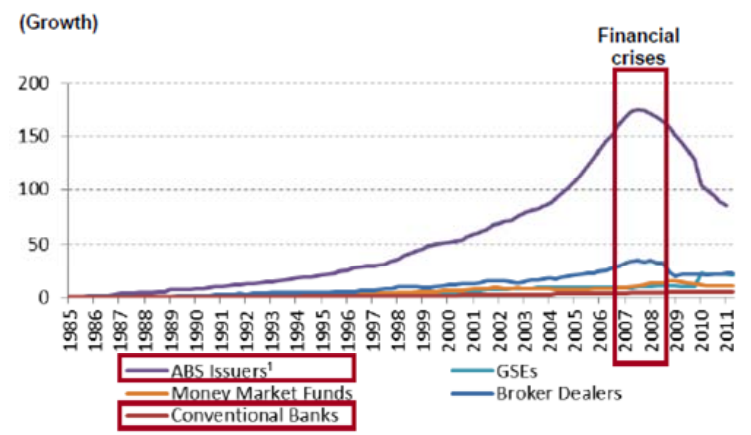

${ }^{1}$ ABS issuers include conduits such as special purpose vehicles. Source: [4].

Figure 1. Growth of the Securities Emissions in the USFinancial Sectors.

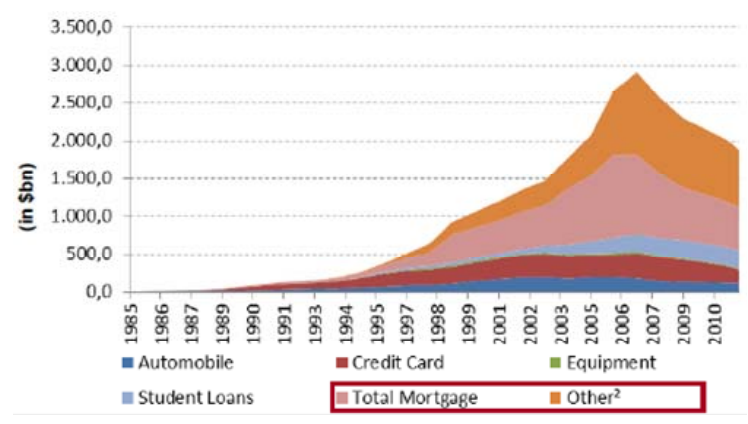

${ }^{2}$ Especially CDOs. Source: [4].

Figure 2. Breakdown of the US-True-Sale-Securitizations.

\subsection{Euro Implementation, Crisis of Credits and Exploding Public Debt}

Parallel to that period of product innovations on the financial markets and the US policy of cheap money to overcome the explosion of the dot-com bubble in 2000 (collapse of the "New Market") and 9/11 in 2001, the implementation of the European currency zone took place. The policy of cheap money was reflected in the development of the US federal funds rate: Since the beginning of the 1980ties this rate was strongly decreasing (also reflecting the declining inflation rates) and reached in the crisis years 2007/08 and following almost zero percent [10]. The crisis of credits arose in several steps:

- The aggressive subprime mortgage policy of the US shadow banking system (including European subsidiary companies, e.g. of Deutsche Bank and many German "Landesbanken") has led to lower lending standards and high-risk mortgage products (like adjustable rate mortgages).

- Regulatory incentives - especially through the Basel Accords - favoring not only OECD public and bank debt but also home mortgages, fueled the credit allocation bias of regular banks.

- The limitation of mortgage liability on housing in 
the US; there is no jointly and severally liability for individuals like in many European countries. ${ }^{12}$

- Malfunctioning of CRA in overlooking the massive problems especially in the shadow banking system.

- The real estate bubble (Ponzi or pyramid scheme) as consequence of careless or even irresponsible policies and investment behavior.

- Breakdown of the overheated real estate markets in the US and Europe as well as the collapse of some shadow (investment) banks.

- Infection of commercial banks and insurances, which have bought junk bonds (especially CDOs).

- Overreaction of the CRA in down-grading the government debt titles in the US and Europe.

- Real collapse of economic activities in single countries accompanied by significant monetary and fiscal policy reactions.

- Decreasing GDP and increasing interest payments on government debt induced enormous budget deficits.

- The enormous increase in refunding needs in some EU member states caused even stronger rising interest rates.

- Single countries came close to bankruptcy (GIIPSC - Greece, Ireland, Italy, Portugal, Spain, and Cyprus).

- Crisis of confidence into the euro system.

- Implementation of financial rescue-parachutes.

Having the development in the euro zone in mind, the implementation of the euro, especially the convergence process before the implementation phase, has reduced the inflation and improved the stability situation in most of the participating member states of the EU. Figure 3 demonstrates that the introduction process of the euro has had an enormous impact on the interest rates in the countries of the euro zone; as an example the net yield of the 10 years government bonds has been chosen. It becomes obvious that the euro implementation has dramatically reduced the interest payments on government bonds especially in the GIIPSC states. In the year of the introduction of the cash euro 2002 the interest rates of almost all member states of the zone came down to the German level. And the spread in between the interest rates remained very close until the beginning of the crisis in the first half of 2007.

Therefore, the implementation of the euro has led to a strong decrease of the interest structures in all the member countries with the exception of Germany, which has already faced before very moderate interest rates due to the stringent monetary policy of the Deutsche Bundesbank. This decline in national interest payments has worked like an economic stimulus package, which caused a

\footnotetext{
${ }^{12}$ The slogan is: Drop of your keys at the bank and get rid of the liability!
}

boom period at least in some member countries, whereas Germany remained in stagnation until competitiveness was recaptured by business restructuring and the measures of the Agenda 2010 (reforms in the social security system).

The low interest rates have not only influenced the economic activities in the member countries but also induced the governments to increase their public debt via the extremely liquid international financial markets. The foreign debt dramatically increased, which at least for some period was hidden because of the remaining moderate interest payments in the public budgets. But if the public debt exceeds a level of in between 60 and 80 percent to GDP, increasing interest rates usually cause a dramatic hike in the interest payments so that exploding budget deficits came to the surface. Hence, these developments induced an increased heterogeneity in the euro zone and the EU. A process of divergence within the economic indicators, especially the internal inflation rates and deficits in foreign trade, came into existence.

Since 2007/08 these processes have step by step and much too slowly been internalized by CRA, which abruptly changed their policies and simultaneously caused a sudden collapse of trust in the governments abilities to manage such a crisis. The reflection on the international financial markets was an explosion of the risk component in the compound interest rates, which also happened in the euro zone and is depicted in Figure 3, too.

The citizen in the GIIPSC countries increased even more the consumption levels, bought goods and services in the few stable countries in the euro zone (Finland, Germany, Luxembourg, and the Netherlands) and a real exodus of capital from the GIIPSC states to the stable Northern member states of the euro zone happened, which is clearly expressed in the so-called target2 balances of the European Central Bank (ECB), reflecting the

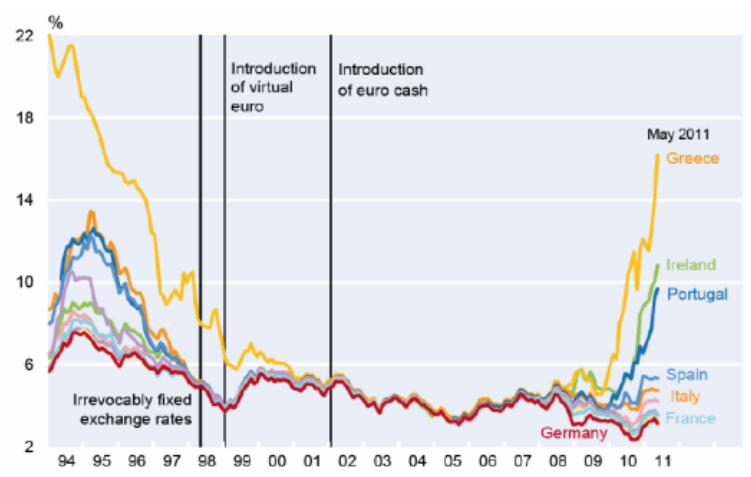

Source: Wikimedia Commons,

http://commons.wikimedia.org/wiki/File:Long-term_interest_rates_(eurozon e)_(1993-2011)de.png

Figure 3. Net Yield of 10 Years Government Bonds in Some Member States of the Euro Zone. 
imbalances in the balances of services and capital movements of the single member states. ${ }^{13}$ Figure 4 represents that since summer 2007 the formerly negligible target2 balances have almost exploded and reached their peak level in July/August 2012. Since then the maximum gap especially in between Germany and Spain but also in comparison to the other member states of the euro zone is slightly diminishing.

The slightly reversal trend in the target 2 balances since fall 2012 is also reflected in the development of the governments bonds net yield. The implementation of the European financial rescue-parachutes (Security Market Program SMP of the ECB, European Fiscal Stability Facility EFSF, European Stability Mechanism ESM, European Fiscal Compact EFC, European Financial Stabilisation Mechanism EFSM) as well as the implicit guarantees communicated by the ECB have obviously temporarily calmed down the actors at the international financial markets so that the long-term interest rates have with some interruptions - also fallen since fall 2012.

The future will show if the political measures having been implemented will be sufficient or not. Only an economic policy within the single member countries which will reduce the public deficits and the interest burden in the budgets seems to be feasible for consolidation and gaining back the trust into the national governments. All the discussions on growth enhancements up to now have been pure rhetoric because nobody has been able to explain how such programs can be financed without endangering the future again - despite of the fact that such concrete programs are badly missing.

\section{Elements of a New (European) Financial Architecture}

The perception of the financial crisis in the affected countries heavily depends on their different interests. Countries with a strong industrial sector are much more interested in a stringent regulation of the financial markets than countries with dominating financial sectors. Therefore, the US and UK are advocating much more liberal regulation than many other European Union member states. And up to now the US have been able to disguise its own debt crisis behind an extremely expansive monetary policy and by accusing the euro zone (especially Germany) for insufficient actions against the euro crisis. Because it seems to be very unlikely that both countries, the US and UK, will change their behavioral patterns in the near future, the other EU member states are pressed to get emancipated from the overseas dependencies in developing an own financial architecture and to start with systems competition against the (neo)

\footnotetext{
${ }^{13}$ For more details on the target2 balances see [11].
}

liberal model.

The problems of the past (ex post elements) can only be solved by (1) involving the financial markets in financing the welfare losses of the crisis via a financial transactions tax (FTT). (2) The owners of the shadow banks have to contribute to the crisis costs and then the lenders dependent on their professionalism (at first large-scale investors, then smaller-scale investors). (3) The taxpayers have to function as lenders of the last resort and not generally taken into liability (only in case of real "systemic" problems).

Protective elements are (1) the clear separation of financial markets in "save harbors" for small-scale investtors and institutional investors (like insurances and pension funds) and risk markets in the sense of Sinn's "casino capitalism" [12], (2) the introduction of quality standards and quality assurance of financial products to safeguard the small-scale investors, and (3) the introduction of liability norms inclusive recall of defective products (like in industry) differentiated for the different risk classes.

Preemptive elements are: (1) Micro-prudential regulation regarding the CEOs and asset managers, which stresses the sustainable management of financial markets by strengthening the regulatory incentives for comprehensible and controllable self-monitoring mechanisms (because CSR is not a pure marketing strategy but an important concern of the employees in the financial markets: "not to bite the hand that feeds you"). (2) Macro-prudential regulation via central banks and financial supervisory bodies by incorporating all financial intermediaryies with exactly adapted regulation elements and a monetary policy strategy to safeguard an appropriate real interest rate in the long-termed development. (3) Microand macro-prudential regulation has to assure risk transparency and general security for small-scale and institutional investors to regain confidence and goodwill into the banking and insurance system, setting the right incentives for further savings and investments.

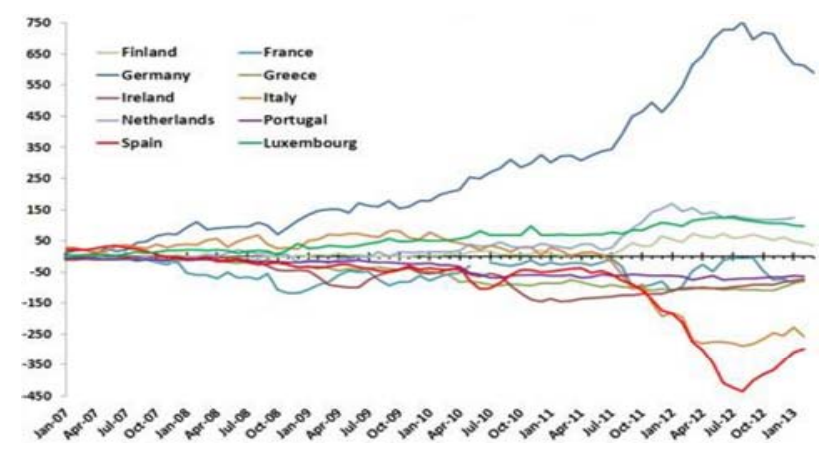

Source: Euro Crisis Monitor, Institute of Empirical Economic Research, Osnabrueck University, http://www.eurocrisismonitor.com/index.htm.

Figure 4. TARGET2 Balances of the ECB (billion euro). 
In case that all these elements alone should not change the regional development patterns it should be made totally clear that a separation of commercial and investment banking would be the consequence, including temporarily capital transactions controls for countries, which do not take part in substantial reforms of the financial sector. These extreme solutions are just mentioned to prevent outsiders from any illusions regarding the will and capabilities to introduce such a new financial architecture. It is much more likely that such a regional solution in the euro zone or the EU (with or without the UK) would lead to a secure "investment harbor", which for sure will attract the international investors if a sufficient real interest rate is guaranteed. Hence, the competition against the neoliberal "casino" model can be won.

Some of the proposed elements might also be of value for the further development in the Chinese financial system, which as mentioned above is much more restricted because it bears a resemblance to the currency theory. This theory holds especially true as not only the credit creation, but also inter-bank as well as cross border capital flows are controlled by the Chinese government and subject to quotas, see Figure 5. Nevertheless, a shadowy side is introduced to this system caused by incentive based credit allocation distortions, restrictive monetary policy and information asymmetries regarding credit risks.

For compensating the lack of investments into private companies and projects also in China an uncontrolled credit market (shadow banking) emerged. According to Credit Suisse estimates, shadow banking in China represents " $25 \%$ of total outstanding credit and half of new credit issued last year" [13]. Lending through the Shadow Banking channel is either conducted via brokered "investment vehicles/trusts" or via three different shadow banking institutions. ${ }^{14}$ The former are mostly designed and sold through regular banks and their less controlled wealth management divisions, which also sell other wealth management products. Hence, savers are being diverted from guaranteed bank deposits, earning negative real interest rates into speculative investments yielding higher returns [14]. The latter are conducted in unregulated peer-to-peer relationships by "small lenders", "pawn shops" and "guarantors" [15]. Both types of shadow Banking include non-standardized and nontransparent lending procedures, therefore, building information asymmetries regarding credit risks. This system obviously also demands a new architecture, which is beyond the scope of this paper.

\section{Conclusions}

The lessons to be learned learn from the last financial

\footnotetext{
${ }^{14}$ According to the Chinese central bank the share of regular bank loans decreased to 58 percent in 2012 (from 95 percent in 2002).
}

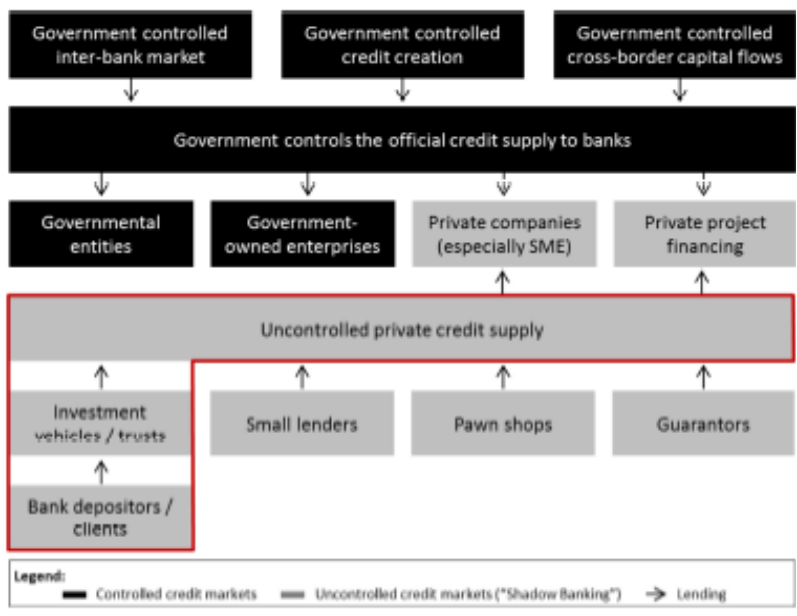

Figure 5. Overview on Chinese Regular and Shadow Banking Sectors.

crises are multifold. The financial sector as part of the service sector has developed too strong self-interests expressed in extraordinary rate of returns, salaries and bonuses - the self-interests of the agents have dominated the ownership-interests of the principals. Therefore, the role of the financial sector has become more and more relevant, almost displacing not only the owners interest but also the political influence. The financial sector has to be reduced to its classical role in serving the real economy under the regulation of strong national states and international organizations. The agents in the financial sector have to be reminded to a personally binding code of conduct so that the peoples' trust in financial institutions is safeguarded and not sacrificed for shortterm personal advantages.

The concentration process within the financial sector has to be stopped by adequate regulation to secure a sufficient degree of competition in between the different institutions of the banking and insurance sector. The orientation only in the direction of the big clients (large enterprises or rich individuals) has to be corrected in favor of a banking and insurance scheme, in which the average citizen is in the focus of financial services. A combination of saving banks, cooperative banks and private banks is of utmost relevance. The old German "house bank" system has been a good example. Private clients and firms have organized their debit and credit relations using such a single bank and the bank managers were perfectly informed about their credit risks being independent from other agents (like the CRA). The Basel Accords have partly destroyed this system being of special value for the SME sector. But in the meantime at least the smaller financial institutions have realized that a return to such a system perhaps leads to a decreasing rate of return but to more safety in investments and higher customer satisfaction. 
Hence, the SME sector needs small and medium-sized banks (SMB) with managers being closely connected to the clients and knowing the individual risk profiles. Multifold securitization bears enormous information losses and the risk of misuse. Multi-agent systems formed by shadow banks and CRA are suffering from serious principal-agent-problems, which are difficult to be adequately controlled by governmental regulation. The influence of agents not adequately controlled contributes to speculative bubbles, pyramid and avalanche effects so that the fundamental economic data are not any longer of relevance for the stock markets and the firm's capitalization. Short-termed speculative interests are then endangering the long term wellbeing of whole societies.

SME as well as SMB have to be supported in the development process until they form the backbones of the economy and a fruitful development strategy. Conventional banking methods have to be combined with modern financial products, which have to be characterized by an adequate rate of return and a transparent risk-reward ratio. Also co-operative credit institutions acting in the interest of the bank clients are a promising approach to limit the influence and the concentration within the globalizing market, which principally creates advantages even for smaller states to get access to the international capital and to overcome situations of national capital shortages. But as important as an efficient SMB system is the trust or mistrust of citizen and business management into the national governance system.

Finally it has to be mentioned that neither the US nor the EU in the future will be the "nucleus of the world". Other regions and emerging countries like China are able to create their own financial architecture, which perhaps might be quite similar to the proposed model in this paper. Then international liquidity is better allocated even in favor of such upcoming nations, which also would guarantee for a sufficient and fair real return on investment to encourage the global savers and investors for additional achievements and to produce increasing welfare for a better world.

\section{REFERENCES}

[1] H.-G. Petersen, Klaus Mueller, "Volkswirtschaftspolitik“, Vahlen, Munich 1999.

[2] D. P. O'Brian, "Foundations of Monetary Economics: Vol. IV: The Currency School”, William Pickering, Lon- don 1994.

[3] D. W. Diamond and P. H. Dybvig, "Banking Theory, Deposit Insurance, and Banking Regulation”, The Journal of Business, Vol. 59, No. 1, 1986, pp. 55-68. doi:10.1086/296314

[4] A. W. Wiegelmann, "Regulierung Des Schattenfinanzsektors,” Dissertation, University of Potsdam, Potsdam 2013 (in press).

[5] K. H. Juettemeier and H.-G. Petersen, “Gloomy Prospects for Social Retirement Insurance - An International Phenomenon,” Intereconomics, Vol. 62, 1982, pp. 11-17.

[6] D. Vink and F. J. Fabozzi, "Non-US Asset-Backed Securities: Spread Determinants and Over-Reliance of Credit Ratings. Yale ICF Working Paper, No. 09-13, June 30, 2009.

[7] H.-G. Petersen, "Principal-Agent-Problems, Risk Management and Social Responsibility: Moral Limitations for Efficient Governance”, Caucasus Institute for Economic and Social Research Tblisi, CIESR Working Paper, 2013 (in press).

[8] D. Klink, "Der Ehrbare Kaufmann - Das urspruegliche Leitbild der Betriebswirtschaftslehre und individuelle Grundlage für die CSR-Forschung, J. Schwalbach (Ed.), Corporate Social Responsibility. Zeitschrift fuer Betriebswirtschaft/Journal of Business Economics, Special Issue 3, 2008, pp. 57-79.

[9] H.-G. Petersen, "Steuern in Fragilen Staaten Empfehlungen fuer die Entwicklungszusammenarbeit," Finanzwissenschaftliche Diskussionsbeiträge, No. 61, 2010, University of Potsdam, Potsdam.

[10] H.-G. Petersen and A.M. Wiegelmann, "Risk Taking, Principal Agent Problems and Breakdown of Corporate Social Responsibility (CSR): How to Reestablish Safe Assets and Capital Funding for Social Security”, Unpublished Paper, Potsdam 2013.

[11] H.-W. Sinn, "Die Target Falle. Gefahren für unser Geld und unsere Kinder“, $4^{\text {th }}$ Ed., Hanser, Munich 2012.

[12] H.-W. Sinn, “Kasino Kapitalismus. Wie es zur Finanzkrise kam, und was jetzt zu tun ist“", $2^{\text {nd }}$ Ed., Econ, Berlin 2009.

[13] Credit Swiss, "Shadow Banking - Road to Heightened Risk”, Credit Swiss Securities Research \& Analytics, February 22, 2013.

[14] X. Gang, "Regulating shadow banking”, retrieved online on May 03, 2013, from http://www.chinadaily.com.cn/opinion/2012-10/12/conten t_15812305.htm, last updated December 10, 2012.

[15] D. Cui, T. Tian, and Z. Wei, "Shadow banking: risky business”, Merrill Lynch, Hong Kong 2012. 